\title{
Uma análise institucionalista do pacto federativo fiscal brasileiro
}

\author{
Marcelo Dalton Dalmolin \\ Universidade do Contestado $(\mathrm{UnC})$ \\ Carlos Eduardo Carvalho
}

Universidade do Contestado (UnC)

Recebido: 08/03/2019 Versão revisada (entregue): 26/08/2019 Aprovado: 19/11/2019

\begin{abstract}
Resumo
Este artigo se propõe a analisar as instituições, em geral, e as instituições formais que conformam o modelo do pacto federativo fiscal brasileiro e seus efeitos nos orçamentos estaduais, em particular. Partindo-se da análise neo-institucionalista sobre o discurso do desenvolvimento, e das regras constitucionais e infraconstitucionais que deram forma ao pacto federativo, à distribuição de competências tributárias e à repartição das receitas tributárias vigentes na República Federativa do Brasil, examinam-se as informações constantes nos orçamentos dos Estados brasileiros de 2002 a 2013. Desta forma, procurou-se identificar os impactos deste modelo institucional, nos orçamentos dos entes subnacionais, agrupados nas regiões geopolíticas do Brasil, cotejando-se a estrutura da carga tributária brasileira e o volume de receitas públicas disponíveis para os Estados. Por fim, foram comparados os tributos federais arrecadados em cada unidade federativa, comparando-os com o volume de receitas disponíveis e o volume de gastos dos Estados, para cotejar o volume de tributos federais e estaduais arrecadados em comparação com o volume de despesas estaduais.
\end{abstract}

Palavras-chave | Brasil; competências tributárias; instituições; pacto federativo.

Código JEL | B15 H77 K37

\section{An institutionalist analysis on the Brazilian fiscal federative pact}

\begin{abstract}
This research aims to analyze the institutions in general and formal institutions, which are conformed to the model of the Brazilian fiscal federal pact and its effects on state budgets in particular. From the neo-institutionalist analysis on the development discourse, and constitutional and ordinary rules that have shaped the federative pact, the distribution of tax powers and allocation of tax revenue in the Federative Republic of Brazil, it went on to analyze the information contained in the budgets of Brazilian states from 2002 to 2013. In this way, it was tried to identify the impacts of this institutional model, the budgets of the subnational entities of the country, grouped in the geo-political regions in Brazil, comparing the structure
\end{abstract}


of the Brazilian tax burden, the volume of public revenues available to states. Finally it was compared the federal taxes collected in each state, comparing them with the volume of available income and the volume of states spending, to compare the amount of federal and state taxes collected compared to the amount of state spending.

Keywords | Brazil; federative pact; institutions; tax competences.

JEL-Code | B15 H77 K37

\section{Un análisis institucionalista del pacto federativo fiscal de Brasil}

\section{Resumen}

Este artículo tiene se propone analizar las instituciones, en general, y las instituciones formales que conforman el modelo del pacto fiscal federal brasileño y sus efectos sobre las finanzas estaduales, en particular. A partir del análisis neo-institucionalista del discurso del desarrollo, y de las normas constitucionales e infra-constitucionales que han dado forma al pacto federativo, la distribución de competencias en materia fiscal y la repartición de los ingresos fiscales en vigor en la República Federativa del Brasil, se examinaron las informaciones contenidas en los presupuestos de los estados brasileros de 2002 a 2013. De esta manera se buscó identificar los impactos de este modelo institucional, en los presupuestos de las entidades sub-nacionales, agrupadas en las regiones geopolíticas de Brasil, examinando la estructura de la carga tributaria brasileña y el volumen de los ingresos públicos disponibles para los Estados. Finalmente, se compararon los impuestos federales recaudados en cada estado, comparándolos con la cantidad de ingresos disponibles y el volumen de gasto de los Estados, para cotejar el volumen de impuestos federales y estatales recogidos en comparación con la cantidad de gastos estaduales.

Palabras clave | Brasil; competencias fiscales; instituciones; pacto federativo.

Codigo JEL | B15 H77 K37

\section{Introdução}

Douglass North, em seu livro Institutions, Institutional Change and Economic Performance (1990), investiga a diferença de desenvolvimento entre os países e aponta as instituições como variável determinante das performances dos estados. As instituições também são o fio condutor com que Aron Acemoglu e James Robinson (2012) analisam a diferença de desenvolvimento econômico ao redor do globo. Identificam que estados com instituições políticas e econômicas inclusivas se desenvolvem mais e melhor do que aqueles que adotam modelos politicamente restritivos e economicamente extrativistas. Edmund Strother Phelps (2013) aponta que os Estados que adotam instituições que premiem a inovação e o empreendedorismo alcançam maior prosperidade que aqueles que adotam instituições mais voltadas à defesa de interesses corporativos. 
A partir dessas premissas analisou-se dentre as instituições brasileiras o chamado Pacto Federativo Fiscal, que decorre da organização do Brasil em uma República Federativa, formada pela União, estados membros e municípios, além do Distrito Federal. Todos com atribuições, competências e fontes de financiamento distintos. Essas fontes de financiamento provêm de tributos próprios, além da reparticipação dos tributos da União com os estados membros e o Distrito Federal, que é assimétrica entre as regiões brasileiras, divididas em Sul, Sudeste, Centro-Oeste, Norte e Nordeste.

A assimetria na repartição do valor arrecadado pelos tributos federais com os estados membros e o Distrito Federal gera diferenças regionais entre o total da imposição tributária sofrida pelos cidadãos e o volume de recursos públicos disponíveis nestes diferentes estados. Essa diferença regional pode caracterizar-se como limitadora ou fomentadora de desenvolvimento pela análise da relação entre o total dos tributos cobrados e o volume das receitas públicas disponíveis para o custeio dos serviços prestados ao cidadão dos diferentes estados.

A carga tributária relativa é determinada pela comparação entre o total de tributos cobrados e o valor dos serviços públicos colocados à disposição do contribuinte. No caso brasileiro, em decorrência das disposições constitucionais acerca do pacto federativo e da repartição assimétrica das receitas tributárias, ocorre significativa diferença entre os estados federados.

O problema que se apresenta é identificar um parâmetro que permita dimensionar essa relação entre o total da imposição tributária sofrida pelos cidadãos e o volume de recursos públicos disponíveis nos estados membro para, então, comparar essa diferença entre os estados.

A primeira parte deste trabalho trata da relação entre as instituições e o desenvolvimento. A segunda parte analisa o Pacto Federativo Fiscal do Brasil e analisa as competências tributárias de cada ente federativo e a repartição das receitas tributárias. A terceira parte analisa e tabula os dados relativos à carga tributária relativa aos estados federados, identificando diferenças regionais no custeio dos serviços públicos.

Tais dados são disponibilizados pela Receita Federal, pelo Instituto Brasileiro de Geografia e Estatística (IBGE) e pela União em seu portal da transparência, que contém um conjunto de bancos de dados tabulados de mesma forma metodológica. Além dos dados disponibilizados pelo Sistema de Informações Contábeis e Fiscais do Setor Público Brasileiro (SICONFI), que apresenta um resumo da execução orçamentária dos estados de 1995 a 2013, incluindo todos os ingressos e saídas de receitas.

De posse de tais dados e aproximações, foi elaborado um indicador que compara a carga tributária relativa aos tributos federais e estaduais em cada estado da federação e a respectiva receita pública disponível em cada um deles. 


\section{As instituições e o desenvolvimento}

Douglas North (1990) examina a natureza das instituições e sua influência na performance econômica e social. Conceitua as instituições de uma sociedade como as "regras do jogo", sejam elas formais, informais ou códigos de comportamento. Podem ser instituições criadas ou instituições que evoluem ao longo do tempo ${ }^{1}$, que estruturam a forma das relações sociais, políticas e econômicas, estabelecendo mecanismos de incentivo positivo e negativo nos comportamentos das pessoas, dos governos e dos agentes econômicos ao longo do tempo, delimitando e definindo o conjunto de escolhas possíveis a esses indivíduos. Explica de que forma as escolhas já tomadas e as estruturas existentes no passado moldam o presente e o futuro, procurando demonstrar que a variável determinante do desenvolvimento dos países não é a geografia, nem os recursos naturais, tampouco a tecnologia, mas, sim, as instituições adotadas por cada sociedade para diminuir os seus custos de transação e garantir os direitos de propriedade. Semelhante abordagem é adotada por Daron Acemoglu e James Robinson no livro "Porque as Nações Fracassam: as origens da riqueza, da prosperidade e da pobreza" (2012).

Acemoglu e Robinson (2012) argumentam que a manutenção de instituições que garantem privilégios e riqueza para uma pequena elite e organizam o Estado e a sociedade em função de seus próprios interesses em detrimento do restante da população é a raiz dos problemas de países com baixos índices de desenvolvimento. Esta defasagem não decorre em função de fatores como a geografia, recursos naturais, clima, características culturais ou políticas e estratégias econômicas equivocadas. Apontam que os países que prosperaram estabeleceram uma sociedade onde os direitos políticos são distribuídos de forma mais igualitária, um Estado em que este - bem como seus governantes - é responsável perante o povo, uma parcela maior da população estava em condições de aproveitar as oportunidades econômicas, bem como o direito de propriedade não é vulnerável em relação a outros agentes econômicos nem ao Estado.

\footnotetext{
${ }^{1}$ Existem dois modelos de direito estatal vigentes no Ocidente. O positivo e o consuetudinário. Os países cujo arcabouço jurídico remonta à tradição romano-germânica utilizam um sistema de direito estatal de matriz positivista, ou seja, fortemente alicerçado em leis e códigos. Nos países que adotam a tradição anglo-saxã, o sistema de direito estatal é de matriz consuetudinária, regem-se basicamente pelos costumes e precedentes, onde a influência de valores e conceitos morais é mais relevante (BONAVIDES, 2001). Quando fala em instituições criadas, North refere-se às leis e códigos. Quando cita instituições que evoluíram ao longo do tempo, trata-se de costumes e precedentes.
} 
Edmund Strother Phelps ${ }^{2}$, no livro Mass Flourishing: how grassroots innovation created jobs, challenge, and change (2013), aborda o que identifica como motores do crescimento econômico: a inovação e o empreendedorismo. Demonstra o que entende como principal ameaça ao crescimento econômico: instituições que protegem interesses corporativos, mais preocupadas em garantir um nível médio de renda e consumo do que garantir o contínuo avanço da inovação. Essa garantia viria, por um lado, pela regulamentação da atividade econômica e proteção de determinados mercados e serviços, e, por outro, pela derivação de parte dos ganhos de produtividade para a manutenção de serviços sociais. Tais modelos de instituições dirigiriam para o Estado os ganhos de produtividade decorrentes da inovação e do empreendedorismo e para a manutenção da proteção dos diversos interesses corporativos. Implicando, desta forma, em um desestímulo ao investimento necessário à inovação e ao empreendedorismo, convergindo à ideia de necessidade de proteção ao direito de propriedade como imprescindível ao incentivo à poupança e ao investimento.

Tais considerações remetem a um complexo conjunto de variáveis interdependentes entre si. Conquanto identificadas as instituições como determinantes do sucesso econômico de uma sociedade, existem diferentes aspectos econômicos, políticos, sociais e jurídicos que as caracterizam. Todavia, a abordagem institucionalista demonstra que fundamentalmente é a garantia dos direitos de propriedade que diferencia o nível de desenvolvimento dos países. Essa garantia refere-se tanto à exclusividade de apropriação dos ganhos de produtividade decorrentes da inovação e da fruição dos rendimentos decorrentes do investimento e do empreendedorismo, quanto à proteção dos ganhos de produtividade e do resultado da iniciativa privada contra o próprio Estado. $\mathrm{Ou}$ seja, a propriedade deve ser protegida inclusive de excessiva tributação por parte do Estado, sob pena de configurar-se em uma instituição que desestimule a inovação, o investimento e o empreendedorismo.

Acemoglu e Robinson (2012) apontam que além da diferença de desenvolvimento entre os países, endogenamente diferentes regiões também apresentam graus diferentes de desenvolvimento. Os Estados podem ser organizados sob diversas formas, com maior ou menor isonomia de instituições formais entre seus entes subnacionais. Países de grandes dimensões territoriais inevitavelmente terão instituições informais e códigos de conduta diferentes entre seus entes subnacionais. No ano de 2013, o Paraná, segundo dados do IBGE divulgados em 19 de novembro de 2015, alcançou o quarto lugar nas economias dos estados brasileiros, respondendo por 6,3\% da economia nacional. Seu Produto Interno

\footnotetext{
${ }^{2}$ Edmund Strother Phelps é reconhecido por sua teoria non-accelerating inflation rate of unemployment. Muito embora não seja incluído entre os economistas institucionais, a partir dos anos 1990 passou a estudar a diferença entre os países, identificando melhores instituições naqueles com taxas de crescimento maiores. Suas conclusões sobre cultura econômica e instituições formais vão ao encontro das definições de Douglas North acerca das instituições de primeiro e segundo níveis.
} 
Bruto (PIB) per capita alcançou o valor de (R\$ mil) 30,26. Ainda em 2013, o PIB per capita do Distrito Federal foi de (R $\$$ mil) 62,86, enquanto o do Piauí registrou ( $\mathrm{R} \$$ mil) 9,81. Tais dados nos permitem apontar uma aguda diferença entre as regiões do Brasil, permitindo perquirir acerca das diferenças das instituições formais brasileiras nos entes subnacionais.

North (1990), ao analisar os motivos das desigualdades, parte do pressuposto de que os países subdesenvolvidos conservam direitos de propriedade ineficientes. A sofisticação e especialização das economias modernas exige uma estrutura institucional que suporte o incremento progressivo da complexidade nas interações entre os agentes econômicos, reguladas por contratos e regras mais rígidas de controle e execução. Distribuindo de forma desigual o poder coercitivo do Estado, possibilita-se que grupos com maior articulação o organizem, bem como suas instituições e as normas regras3, convergindo ao raciocínio de Acemoglu e Robinson, oportunizando-se que essa organização estatal possa se dar em benefício destes grupos em detrimento de outras formas institucionais que beneficiem o conjunto da nação. Instituições melhores para o crescimento econômico e o bem-estar das pessoas podem ser preteridos em favor de outras que são melhores para quem detém o controle político, ou até mesmo para a manutenção deste controle político. (ACEMOGLU; ROBINSON, 2012).

Por sua vez, as atuais sociedades ocidentais adotaram a partir da segunda metade do Século XX, em maior ou menor grau, um modelo estatal de welfare state ${ }^{3}$. Ao par do desenvolvimento de instituições sofisticadas que permitam a diminuição das incertezas, implementaram um sistema de proteção social e corporativismo preocupados em garantir um nível de renda e consumo para todos (PHELPS, 2015). Porém, a dimensão dos recursos necessários à manutenção desse modelo pode implicar, pela via inversa, em um desestímulo ao empreendedorismo e investimento, visto que grande parte dos ganhos de produtividade daí decorrentes acabam sendo apropriados pelo Estado para a manutenção do sistema de proteção social. Igualmente podem configurar-se em instituições inibidoras da inovação com o intuito de garantir ocupações e atividades econômicas já estabelecidas e protegidas. $^{4}$

O alcance das garantias do direito de propriedade (aqui considerada, inclusive, em oposição ao Estado ou a determinados grupos hegemônicos dentro dele) e as instituições determinantes dos custos de transação de um lado, e o sistema de

\footnotetext{
${ }^{3}$ Estado Social ou Estado de Bem-Estar Social.

4 Phelps utiliza como exemplo de proteção corporativista a reação ao redor do mundo ao aplicativo Uber de compartilhamento de veículos, que enfrenta forte resistência de taxistas. Os ganhos de produtividade decorrentes de seu uso (que aumenta a utilização dos veículos já em circulação, com um custo financeiro e ambiental significativamente menor do que o dos táxis) atingem o faturamento de uma categoria expressiva, pois os ganhos de produtividade decorrentes de seu uso são diretamente proporcionais à diminuição do faturamento dos táxis, expressando perfeitamente o conceito de destruição criativa. Entrevista feita à Revista Veja, edição 2448 (ano 48 , N. 42, 21 out. 2015).
} 
proteção social e das corporações adotadas por um Estado de outro, vão determinar no longo prazo os incentivos à inovação, ao investimento e ao empreendedorismo. Quanto maior esse incentivo, maiores os ganhos de produtividade e o acúmulo de ativos. Quanto mais garantidos os direitos de propriedade pelas instituições, menores os custos de transação e maior a eficácia das trocas econômicas.

Os direitos de propriedade necessitam de garantia em face às incertezas, as quais podem ser decorrentes de informação imperfeita (measurement) ou da motivação dos outros agentes (enforcement). North (1990), constrói sua teoria analisando de que forma as instituições garantem os direitos de propriedade em relação a tais incertezas e qual o volume dos custos de transação (trocas econômicas) necessários para as mesmas. Porém, exclui de sua teoria a motivação e a intenção do próprio Estado enquanto também um agente econômico em sua relação com os demais agentes econômicos. Também não considera a motivação dos agentes políticos, bem como o interesse de grupos regionais ou corporativos detentores de influência sobre esses agentes.

A base de sua análise parte da economia norte-americana, classificada por Phelps (2013) como relativamente capitalista. Os serviços típicos dos Estados de BemEstar Social ali são menos presentes do que na maioria dos países da Europa Ocidental, o que pode ser a razão pela qual não aborda fatores como a intenção deliberada de manutenção de instituições, que, na abordagem de Acemuglu e Robinson (2012) representam interesses dos agentes políticos, ou econômicos com influência junto aos políticos. Phelps (2013) aprofunda essa discussão demonstrando a suscetibilidade dos estados e agentes políticos às pretensões não somente dos agentes econômicos, mas também dos interesses corporativos e de demandas de segmentos e regiões influentes da sociedade.

Nos países que adotam o modelo estatal de welffare state, inúmeros serviços públicos são prestados não pela iniciativa privada, mas pelo próprio Estado. Esses serviços não são custeados por preços, mas por tributos, alterando drasticamente os custos de transação envolvidos em toda troca econômica e tornando impossível aos demais agentes econômicos qualquer tipo de escolha na obtenção desses. Igualmente, não há possibilidade de escolha quanto ao volume e alcance de serviços públicos não relacionados ao mercado, como assistência social, segurança interna, externa e administração da Justiça. North (1990) não coloca na equação a garantia dos direitos de propriedade em relação ao Estado ou aos preços por ele praticados, em sua influência nos demais custos de transação, tampouco em relação ao conjunto de atores sociais que detêm o domínio político deste.

Em Estados complexos, a repartição das atribuições, das competências, da representação política, a definição do tamanho e funções do Estado tem ainda de equacionar questões relativas à participação econômica e à carga tributária relativa de cada um dos entes subnacionais. O peso da imposição tributária em cada um 
dos entes subnacionais nos países que adotam o modelo de Estado Complexo não pode ser comparado sem que sejam observados os serviços públicos mantidos pela tributação. A proporcionalidade entre o total da imposição e o volume dos serviços públicos postos à disposição dos cidadãos é que vai determinar a carga tributária relativa de cada ente analisado, bem como o custo global dos serviços públicos colocados à disposição de seus cidadãos.

Acemoglu e Robinson apontam que Estados Nacionais podem adotar instituições que não garantam os direitos de propriedade, agindo no interesse da parcela da população que detém o domínio político e econômico. Enquanto North analisa a motivação humana no nível dos agentes econômicos, Acemoglu e Robinson analisam a motivação de agentes e grupos políticos ao adotar instituições que assegurem seu empoderamento. Estes, ao invés de adotar instituições que são melhores para o crescimento econômico, adotam outras que são ainda melhores para eles mesmos.

Segundo Phelps (2013), além do conflito de interesses entre os agentes políticos e os entes jurisdicionados, apontados por Acemoglu e Robinson, pode ocorrer ainda um conflito entre categorias dos próprios agentes econômicos, incluídos, inclusive, interesses regionais ou subnacionais, aos quais os agentes políticos, necessitando de sustentação política, aquiescem.

Agentes que Phelps (2013) chama de categorias corporativistas, pressionam os grupos políticos para que adotem normas que protejam os seus próprios interesses. Quando maior for a representatividade de cada categoria, maior poder político ela tem para influenciar as tomadas de decisões e as normas (e por conseguinte as instituições) em seu benefício. A proteção desses interesses pode resultar na imposição de barreiras à inovação. Se um determinado avanço tecnológico ou de governança permite a diminuição dos recursos necessários à elaboração de um produto ou prestação de um serviço (no processo que Schumpeter classifica de destruição criativa), isso afetará os agentes econômicos envolvidos naquela cadeia produtiva.

Se estes agentes tiverem influência política poderão conseguir que os atores políticos determinem barreiras àquela inovação. Phelps define os grupos com interesses comuns de Corporativos. Tais instituições, ao impor barreiras à inovação, e, consequentemente, à diminuição de custos de produção e transação, configuram-se como instituições limitadoras do desenvolvimento, pela mitigação de dois aspectos do direito de propriedade 6, o uso e a fruição da inovação, limitando a propriedade sobre a inovação.

Por outro lado, interesses corporativos também podem efetuar pressão sobre os agentes políticos para a manutenção de programas de garantias de níveis mínimos de renda e consumo. Isso demanda maior tributação da iniciativa privada, e igualmente importa na mitigação do direito de propriedade ao par do respectivo aumento dos custos de transação decorrente da tributação. Phelps (2013), ainda 
aponta que os países que adotaram um modelo de Estado de Bem-Estar Social relativamente corporativistas apresentam performances de participação dos trabalhadores na renda, inclusão social e indicadores de produtividade menores do que os dos países que adotaram um modelo relativamente capitalista. ${ }^{5}$

Isso por lhes faltar instituições e cultura para permitir, estimular e incentivar a experimentação, a exploração, o investimento e o empreendedorismo. Phelps (2013), destaca um conjunto de atitudes, normas de comportamentos e suposições acerca de negócios, trabalho, governança, repercussão social que afetam a geração de recompensas não materiais, indiretamente pela influência das instituições e políticas e diretamente pela influência nos motivos e expectativas dos participantes. O conjunto das recompensas não materiais está ligado, portanto, à homogeneidade de pensamento e às causas culturais, classificadas por North (1990) como instituições de primeiro nível, e às questões institucionais, apontadas como sendo de segundo nível.

Phelps (2013), ao analisar as disparidades entre as modernas economias relativamente capitalistas e as corporativistas, enumera as causas institucionais e culturais destas disparidades. Entre as institucionais cita os direitos de propriedade, estruturas jurídicas e políticas que garantem esses direitos de propriedade, o estabelecimento e regulação das instituições financeiras, englobando os mercados financeiro e o de valores mobiliários. Cita como causas culturais os valores associados ao interesse pelo trabalho, aceitação de novas ideias, desejos e iniciativas pessoais, disponibilidade e aceitação de mudanças e a vontade e aceitação da competição. O conjunto de tais causas define como representativas dos valores das economias relativamente capitalistas. Ao definir e garantir direitos de propriedade adequados, arranjos institucionais eficientes levarão organizações e indivíduos a investir em atividades economicamente produtivas, na acumulação de capital e conhecimento (GALÍPOLO; GALA; FERNANDES, 2008). Acemoglu e Robinson (2012), bem como Phelps (2013), assinalam que as instituições devem ser de tal modo arranjadas que os ganhos de produtividade obtidos não possam ser excessivamente tributados. Isso para que não sejam desestimulados o investimento e a inovação ou que se conformem como instituições extrativistas.

Instituições econômicas extrativistas apresentam como características cruciais uma estrutura que permite a determinada parcela da sociedade, via de regra aquela que concentra o poder político (ou com influência sobre os poderes políticos instituídos) extrair recursos da maioria da população economicamente ativa e um sistema ineficiente de proteção dos direitos de propriedade. Dessas duas características decorrem outras, como a dificuldade de grande parte da população de acumular ativos; o baixo incentivo ao investimento e à atividade econômica;

\footnotetext{
${ }^{5}$ Phelps classifica as economias ocidentais em relativamente socialistas-corporativistas e relativamente capitalistas.
} 
pouco incentivo à inovação e ausência da chamada destruição criativa. Essa ausência de destruição criativa, por sua vez, encontra-se relacionada à manutenção de direitos corporativos, pela forte pressão que os segmentos econômicos regulamentados mantêm sobre a classe detentora do poder político a fim de manter inalterados seus mercados.

Esses aspectos também são identificados por Phelps (2013) quando trata das diferenças de desempenho econômico entre economias relativamente capitalistas e as socialistas. Sua abordagem trata a inovação e a destruição criativa como contrárias aos interesses corporativos, e centraliza sua análise nas economias da América do Norte e Europa Ocidental. Ela permite verificar naquelas economias relativamente socialistas características identificadas por Acemoglu e Robinson (2012) nas economias extrativistas: derivação de ativos de uma parcela da população para outra com forte influência política e o desestímulo à inovação por parte dos detentores do poder político a fim de evitar a destruição criativa e manter o status quo. O grau de estímulo ou desestímulo à inovação e o nível de apropriação de ganhos dos cidadãos é que posiciona, para Phelps, a economia de um Estado como relativamente capitalista ou relativamente socialista, centrando seu estudo na inovação e nos interesses corporativos.

O crescimento econômico em países com instituições extrativistas se dá pelo sistema de transferência de renda de uma parcela da população para outra. No caso do pacto federativo brasileiro, o sistema de repartição de receitas tributárias configura-se, subnacionalmente, como uma instituição com a característica de direcionar recursos públicos de um recorte territorial para outro. Caracteriza-se também pela discrepância de rendimento verificada entre os trabalhadores que desenvolvem sua atividade na iniciativa privada e aqueles empregados no serviço público. Uma das consequências dessa diferença reflete-se no contínuo encaminhamento ao serviço público dos alunos com maior aproveitamento acadêmico, que preferem a estabilidade deste ao risco de dedicar-se à iniciativa privada.

O conceito de instituições extrativistas utilizadas por Acemoglu e Robinson (2012), enumera características que vêm ao encontro de algumas das utilizadas por North (1990) ao conceituar instituições limitadoras do desenvolvimento, bem como com algumas outras utilizadas por Phelps (2013) ao conceituar instituições de natureza corporativa. Por sua vez, os conceitos de centralização governamental e descentralização administrativa de Tocqueville (2005) convergem às características das instituições políticas definidas por Acemoglu e Robinson (2012) fomentadoras de um círculo virtuoso: centralização política que permita a imposição da lei e da ordem, ou seja, que possibilitar o florescimento do Estado de Direito (melhor definidos por Tocqueville quanto à sua natureza, como uma centralização de governo e a existência de uma única jurisdição efetivamente soberana em um dado recorte territorial), a par de um pluralismo político, que fomente o estabelecimento de procedimentos decisórios coletivos e a participação 
de uma maioria no processo de tomada de decisões. Até o conceito de que é possível crescimento econômico por algum tempo em Estados com instituições extrativistas, mas que somente aqueles com modelos inclusivos conseguem alcançar um processo de desenvolvimento sustentado, ressoa na afirmação de Tocqueville de que a centralização administrativa pode surtir efeitos passageiros, mas não a prosperidade duradoura de um povo.

Acemoglu e Robinson (2012), igualmente identificam nos Estados com instituições políticas consideradas inclusivas um crescimento econômico sustentável. Essa característica seria decorrente do incentivo à inovação, pela possibilidade de o sujeito acumular grande parte dos ativos dela decorrentes. Isso seria possível pela garantia dos direitos de propriedade. Identificam também que instituições econômicas consideradas inclusivas não restringem a destruição criativa. Phelps (2013), igualmente afirma que os Estados que têm melhor desempenho econômico e cidadãos com maior nível de renda e consumo são aqueles cujas instituições e políticas incentivam a inovação. Onde, também, o Estado não se aproprie em excesso dos ganhos de produtividade derivados desta inovação.

Por outro lado, ressoando os conceitos de Acemoglu e Robinson (2012) acerca das instituições extrativistas que derivariam para uma parte da sociedade os ativos produzidos pelo conjunto do Estado, Phelps (2013) identifica as instituições corporativas como aquelas que no lugar da competição elegem a coordenação e o controle da atividade econômica por parte do Estado, que mantêm fortes vínculos com os agentes econômicos, notadamente, o grande capital. Instituições corporativas fazem com que boa parte da atividade econômica dependa do Estado e não da lógica do mercado. O Estado consegue determinar qual setor da economia vai crescer, mediante subsídios, incentivos fiscais e operações financeiras.

\section{O pacto federativo fiscal brasileiro}

Em Estados organizados economicamente sob a forma de economias de mercado, a opção política constitucional exige que seja assegurada a livre iniciativa e a propriedade privada. Ao delegar aos agentes econômicos privados a produção, troca e acumulação de ativos, o Estado, para custear os serviços públicos, necessita tributar parte destas atividades. As escolhas sobre a forma de exploração da atividade econômica, e a existência ou não de propriedade privada são exemplos de escolhas políticas constitucionais. As limitações constitucionais ao poder de tributar são exemplos de princípios jurídicos constitucionais, pois, decorrentes diretos de uma escolha política, vão informar de que forma $\mathrm{O}$ ordenamento jurídico limitará o poder do Estado. 
As necessidades públicas compreendem as despesas feitas por parte do Estado, para suprir os serviços a seu encargo, previstos no bojo de suas instituições formais em geral, e, no caso do Brasil, na Constituição Federal de 1988, em particular. $\mathrm{O}$ alcance dos serviços aos quais o Estado se obriga perante os seus cidadãos irá determinar de forma fundamental a natureza das instituições, bem como se serão mais orientadas às políticas inclusivas ou às políticas extrativistas, corporativas ou mesmo inibidoras do desenvolvimento.

Esses serviços podem ser divididos em duas categorias: aqueles essenciais de Estado, necessários à existência de um governo centralizado (ASSEMOGLU; ROBINSON, 2012), quais sejam a segurança interna e externa e a administração da justiça. Bem como aqueles serviços escolhidos pela própria sociedade para serem supridos pelo esforço coletivo, seja a intervenção na economia, a redistribuição de ativos ou a prestação de serviços relacionados aos direitos sociais, como saúde, educação e previdência social. Colocados em uma escala, os serviços essenciais de Estado relativos à segurança interna, externa e à administração de justiça compõe aqueles típicos de países com arranjo econômico liberal. Os demais serviços sociais, de redistribuição de ativos e dirigismo econômico são relacionados aos Estados organizados sob a forma de Estados de Bem-Estar Social. A natureza e alcance dos serviços prestados pelo Estado, e o volume de recursos necessários para sua manutenção é que vão definir o grau de dependência que a iniciativa privada e o grande capital, em especial, vão ter em relação ao Estado e o volume da carga tributária necessária para a manutenção destes serviços. (PHELPS, 2013).

Porém, muito embora não exista na relação entre o Estado e o contribuinte, direito a uma contraprestação específica, bilateral, relacionada ao montante pago individualmente, a garantia do direito de propriedade prevista no texto constitucional brasileiro exige que a imposição tributária cobrada de toda a sociedade se dê dentro de limites aceitáveis, sob pena de a imposição tributária caracterizar-se como extrativista, nos termos de Acemoglu e Robinson (2012). Na competição dos interesses dos agentes jurisdicionados, dos agentes econômicos e do Estado, infere um ponto de equilíbrio entre as repartições dos ganhos de produtividade. Estes devem ser de tal forma repartidos que, enquanto ainda estimulem a acumulação de capital do particular, permitam o reconhecimento que o valor pago pelos serviços públicos seja menor que o recurso eventualmente destinado privadamente para a realização da mesma atividade, pela economia de escala do Estado ao efetuar o serviço (NORTH, 1990).

O Estado ao fornecer os serviços públicos obtém ganho de escala no custo deles, pelo volume prestado. Assim, do ponto de vista econômico, ao cidadão é mais vantajoso sofrer a imposição tributária para ver satisfeitas essas necessidades do que as adquirir pessoalmente, uma vez que o total pago na forma de tributos é menor do que o que despenderia para obter individualmente igual serviço. 
Contrário sensu, se o volume da imposição tributária representa um custo total superior ao que o cidadão despenderia para obter os mesmos serviços individualmente, isso representa um incremento nos custos de transação e violação ao seu direito de propriedade, pela expropriação exacerbada de seus ganhos de produtividade. Essas últimas características são próprias de instituições classificadas por Acemoglu e Robinson (2012) como extrativistas e por Phelps (2013) como corporativas. Nessas, a diferença entre o custo efetivo dos serviços prestados e o total da imposição tributária seria apropriada de parte da população em benefício de outra, identificada como a elite. Sob a análise de North (1990), tal arranjo importaria em uma instituição que majorasse em demasia os custos de transação. Analisado sob os argumentos de Phelps (2013), importaria numa estrutura de proteção de interesses corporativos. Todas as três análises, ao contrário de significarem interpretações distintas, convergem para uma mesma conjuntura, explicando o mesmo fenômeno em três momentos distintos da cadeia produtiva.

Do ponto de vista do agente econômico, que vê apropriada uma parte significativa de seus ganhos com as trocas econômicas em descompasso com o volume dos serviços públicos ofertados, essa apropriação representa uma mitigação de seu direito de propriedade e de acumulação ou consumo dos ativos decorrentes de sua atividade. Quanto ao aspecto dos direitos de propriedade, North, Phelps e Acemoglu e Robinson são uníssonos. Do ponto de vista microeconômico das trocas econômicas em si, uma tributação assim configurada importaria em uma majoração dos custos de transação, diminuindo a eficácia das trocas econômicas (NORTH, 1990). Do ponto de vista da alocação desses recursos assim apropriados, importaria na manutenção de direitos corporativos de alguns setores privilegiados da atividade econômica, cujo sucesso passa a depender não da lógica do mercado, mas da atuação estatal mediante subsídios, incentivos fiscais e operações financeiras, bem como de grupos sociais e atividades organizadas e articuladas na proteção de seus interesses em detrimento da inovação (PHELPS, 2013). Do ponto de vista da atividade financeira do Estado, importaria em uma estrutura institucional extrativista, que faria convergir para as elites detentoras ou influentes junto ao poder político parte dos ganhos obtidos na atividade econômica (ACEMOGLU; ROBINSON, 2012).

Ao tratar das instituições, Douglas North (1990) identificou duas espécies de instituições, as formais e as informais. As instituições formais encampam o ordenamento jurídico, desde as normas constitucionais no ápice, às demais regras infraconstitucionais, notadamente as leis ordinárias, até o primeiro degrau, que são os contratos e que fazem lei entre as partes (NORTH, 1990). Dentro dessa hierarquia, as normas inferiores devem obediência às superiores até culminar no texto constitucional. A Constituição Federal Brasileira de 1988 encerra normas principiológicas e normas regras. Segundo José Joaquim Gomes Canotilho (1993), 
tais normas principiológicas dividem-se em princípios políticos e princípios jurídicos constitucionais.

Os princípios políticos constitucionais são definidos como os princípios estruturantes do Estado, que definem a sua forma, formato e regimes de governo, a separação e competência dos poderes constituídos. Já os princípios jurídicoconstitucionais são aqueles informadores do sistema jurídico adotado pela Constituição, sendo o fundamento para a interpretação, integração, conhecimento e aplicação do direito positivo, limitando os poderes do Estado e informando a atuação estatal (CANOTILHO, 1993).

No caso brasileiro, tais princípios já se vislumbram na nomenclatura do país: República Federativa do Brasil e evidenciam que entre as escolhas políticas estão a adoção do tipo republicano de governo e do modelo de Estado Federativo (CANOTILHO, 1993).

O Brasil é constituído como um Estado composto sob a forma de uma República Federativa (CANOTILHO, 1993). No federalismo o Estado é formado pela união de entes políticos dotados cada um de personalidade jurídica própria e que se sobrepõem em competências, prerrogativas e atribuições em um mesmo território, cujos elementos infranacionais são dotados de autonomia política, administrativa e financeira. Nesse arranjo se equilibram as vontades parciais dos entes federados e as vontades gerais da União, atribuindo-se aos primeiros sua própria autoorganização (NOVELINO, 2013). Os Estados organizados sob a forma de federações podem ser caracterizados como mais ou menos concentradores de poder político, mais ou menos concentradores de capacidade financeira ou, ainda, mais ou menos concentradores de atribuições administrativas sem que necessariamente haja equivalência entre suas competências e atribuições (NOVELINO, 2013).

Como nas complexas economias de trocas capitalistas ocidentais, a justificativa de validade e legitimidade para a cobrança de tributos para além da manutenção dos serviços essenciais de Estado relativos à segurança interna e externa e à administração da justiça (sem os quais não há centralização governamental necessária à própria existência do Estado) reside na suposta economia de escala obtida pelos entes estatais ao prestar serviços públicos.Essa economia de Escala resulta em uma relação de custo benefício mais vantajosa para o cidadão, que pagaria um valor maior se adquirisse por conta própria tais serviços.

A análise do grau de autonomia de um ente federado passa pela verificação das atribuições quanto à prestação dos serviços públicos, sua capacidade de investimento e o volume de receitas disponíveis para a realização destes serviços. Esse por sua vez não é equivalente ao total dos tributos cobrados em seu recorte territorial, pelos critérios assimétricos de repartição das receitas tributárias.

A Constituição Federal estipula que parte das receitas da União sejam repassadas para os estados e municípios. Por sua vez, também determina que parte das 
receitas dos estados sejam repartidas aos municípios de sua jurisdição. Essas duas previsões constitucionais - a atribuição de competências e a repartição de receitas tributárias - compõem o aspecto econômico-financeiro do Pacto Federativo e irão determinar o volume de receitas públicas disponíveis para cada ente federado, sendo denominado de Pacto Federativo Fiscal.

São de competência privativa da União os impostos de Renda, Territorial Rural, sobre Grandes Fortunas, sobre Produtos Industrializados, sobre Operações Financeiras, de Importação e de Exportação. Por sua vez, são de competência privativa dos estados os impostos sobre a Circulação de Mercadorias e Serviços (ICMS), sobre a Transmissão por Causa Mortis ou Doação e sobre a Propriedade de Veículos Automotores.

A estipulação das competências tributárias pela Constituição Federal assegura que os entes federados terão receitas próprias para suprir seus gastos, oriundos dos tributos de sua competência. Os recursos assim arrecadados representam apenas uma parte dessas receitas próprias. O restante deriva da repartição das receitas tributárias, em que a União é obrigada, constitucionalmente, a repassar parte de sua arrecadação para estados e municípios, e os primeiros igualmente obrigados ao repasse de parte de sua arrecadação aos municípios. Essa estipulação constitucional que importa nos recursos próprios de cada ente subnacional é o conteúdo do Pacto Federativo Fiscal. Na composição das receitas tributárias de cada ente federado, verifica-se que nos anos compreendidos entre 2008 e 2012 as participações na arrecadação total orbitaram em torno de $70 \%$ para a União, 25\% para os estados e 5\% para os municípios, segundo dados disponibilizados pelo Centro de Estudos Tributários e Aduaneiros da Receita Federal do Brasil nas publicações da Carga Tributária Brasileira 2012/2013, conforma a Tabela 1:

\section{Tabela 1 - Evolução da Participação dos Entes Federados na arrecadação total de 2008 a 2013}

\begin{tabular}{lcccccc}
\hline Ente Federativo & 2008 & 2009 & 2010 & 2011 & 2012 & 2013 \\
\hline Governo Federal & $69,51 \%$ & $68,91 \%$ & $69,03 \%$ & $70,04 \%$ & $69,06 \%$ & $68,92 \%$ \\
Governo Estadual & $25,36 \%$ & $25,63 \%$ & $25,46 \%$ & $24,44 \%$ & $25,17 \%$ & $25,29 \%$ \\
Governo Municipal & $5,13 \%$ & $5,46 \%$ & $5,51 \%$ & $5,52 \%$ & $5,77 \%$ & $5,79 \%$ \\
\hline Total da Receita Trib. & $100,00 \%$ & $100,00 \%$ & $100,00 \%$ & $100,00 \%$ & $100,00 \%$ & $100,00 \%$
\end{tabular}

Fonte: dados da pesquisa (2016).

Deste total de receitas percebidas pela União, apenas uma pequena parte é partilhada e volta aos estados na forma do Fundo de Participação de Estados e Municípios (FPE e FPM). O Artigo 159 da Constituição Federal determina que a União entregará 48\% do total arrecadado com os impostos de Renda e sobre Produtos Industrializados, sendo que, destes, $21,5 \%$ e 22,5\% aos fundos de 
participação dos estados e municípios respectivamente. O restante é destinado aos fundos constitucionais especiais para as regiões Centro-Oeste, Norte e Nordeste, como demonstrado na Tabela 2.

Tabela 2 - Receita Pública disponível dos entes federados após a repartição
das receitas tributárias
\begin{tabular}{lcccc}
\hline Ente Federativo & Originário & Partilhado & Recebido & Final \\
\hline Governo Federal & $68,92 \%$ & $9,44 \%$ & & $59,48 \%$ \\
Governo Estadual & $25,29 \%$ & $6,07 \%$ & $4,22 \%$ & $23,44 \%$ \\
Governo Municipal & $5,79 \%$ & $0 \%$ & $10,50 \%$ & $16,29 \%$ \\
Fundos Constitucionais & & & $0,79 \%$ & $0,79 \%$ \\
\hline Total & $100,00 \%$ & & $100,00 \%$ \\
\hline
\end{tabular}

Fonte: dados da pesquisa (2016).

\section{A carga tributária relativa nos estados}

A União mantém um banco de dados com as informações da execução orçamentária dos estados membros, denominado Sistema de Informações Contábeis e Fiscais do Setor Público Brasileiro (SICONFI), desde 1995, onde reúne um resumo de todos os ingressos e saídas de dinheiro nos entes estaduais. Igualmente estão disponíveis as informações relativas à arrecadação anual de tributos federais em cada uma das unidades da federação desde 2000 e até 2015. No cálculo dos valores arrecadados foram excluídos pelo Tesouro Nacional os valores recolhidos à previdência social, compondo-se da soma dos tributos federais excetuando-se as contribuições sociais para o Instituto Nacional do Seguro Social (INSS). Os dados relativos aos ingressos de recursos são classificados em dois grandes grupos: receitas correntes e receitas de capital. Receitas correntes são recursos oriundos da atividade tributária do Estado, englobando aquelas advindas dos tributos da competência do próprio ente (receitas tributárias), e receitas oriundas da repartição das receitas tributárias (transferências correntes). Essas informações podem ser cruzadas com os dados relativos à arrecadação de tributos federais nos estados.

Dentre as receitas tributárias próprias dos estados, a rubrica com a arrecadação mais importante é a relativa ao Imposto sobre a Circulação de Mercadorias e Serviços (ICMS). O ICMS incide sobre o valor agregado em cada fase da operação de industrialização ou comércio de bens. A relação entre o ICMS e a atividade econômica pode ser demonstrada comparando-se os dados relativos ao PIB dos estados e o volume total de arrecadação do ICMS, como se vê na Tabela 3. 

Tabela 3 - Comparação do PIB estadual e a arrecadação de ICMS nos
estados

\begin{tabular}{lrlr}
\hline Estado & \multicolumn{1}{c}{ PIB } & Estado & \multicolumn{1}{c}{ ICMS } \\
\hline São Paulo & 1.708 .221 .000 .000 & São Paulo & $112.702 .386 .732,09$ \\
Rio de Janeiro & 626.320 .000 .000 & Minas Gerais & $35.244 .662 .007,75$ \\
Minas Gerais & 486.955 .000 .000 & Rio de Janeiro & $33.483 .292 .024,99$ \\
Paraná & 332.837 .000 .000 & Rio Grande do Sul & $23.497 .323 .275,69$ \\
Rio Grande do Sul & 331.095 .000 .000 & Paraná & $20.725 .794 .220,02$ \\
Santa Catarina & 214.217 .000 .000 & Bahia & $15.682 .057 .758,24$ \\
Bahia & 204.265 .000 .000 & Santa Catarina & $13.939 .666 .072,14$ \\
Distrito Federal & 175.363 .000 .000 & Goiás & $11.828 .015 .179,66$ \\
Goiás & 151.010 .000 .000 & Pernambuco & $11.543 .355 .297,32$ \\
Pernambuco & 140.728 .000 .000 & Espírito Santo & $8.605 .920 .353,96$ \\
Pará & 120.949 .000 .000 & Ceará & $8.565 .578 .586,25$ \\
Espírito Santo & 117.043 .000 .000 & Pará & $7.684 .241 .280,01$ \\
Ceará & 108.796 .000 .000 & Mato Grosso & $7.578 .054 .569,89$ \\
Mato Grosso & 89.124 .000 .000 & Amazonas & $7.425 .753 .698,97$ \\
Amazonas & 83.293 .000 .000 & Mato Grosso do Sul & $6.239 .509 .704,74$ \\
Mato Grosso do Sul & 69.118 .000 .000 & Distrito Federal & $6.174 .900 .779,79$ \\
Maranhão & 67.593 .000 .000 & Maranhão & $4.345 .797 .509,03$ \\
Rio Grande do Norte & 51.446 .000 .000 & Rio Grande do Norte & $3.936 .626 .409,92$ \\
Paraíba & 46.325 .000 .000 & Paraíba & $3.853 .739 .764,76$ \\
Alagoas & 37.223 .000 .000 & Alagoas & $2.745 .420 .477,04$ \\
Sergipe & 35.193 .000 .000 & Rondônia & $2.669 .575 .227,83$ \\
Piauí & 31.240 .000 .000 & Piauí & $2.658 .793 .241,37$ \\
Rondônia & 31.092 .000 .000 & Sergipe & $2.500 .900 .371,50$ \\
Tocantins & 23.778 .000 .000 & Tocantins & $1.660 .021 .503,62$ \\
Amapá & 12.762 .000 .000 & Acre & $789.110 .800,53$ \\
Acre & 11.440 .000 .000 & Amapá & $784.483 .253,11$ \\
Roraima & 9.027 .000 .000 & Roraima & $518.179 .095,16$ \\
\hline Fonte: Dados da pesa & &
\end{tabular}

Fonte: Dados da pesquisa (2016).

Outra comparação indica o total da participação do ICMS e das transferências correntes nas receitas correntes líquidas. As transferências correntes líquidas englobam o volume total de transferências da União. Assim, além das chamadas transferências constitucionais decorrentes da repartição das receitas tributárias previstas na constituição, as transferências correntes ainda englobam as voluntárias, que são aquelas relativas às obras e aos convênios. Essa comparação permite demonstrar o quanto a atividade econômica de cada ente federativo influencia o seu volume de receitas, servindo de parâmetro para demonstrar o grau de independência econômica em relação ao governo da União, como verifica-se nos gráficos 1 e 2 . 
Gráfico 1 - Participação do ICMS e das transferências correntes no total das receitas correntes por região para o ano de 2002

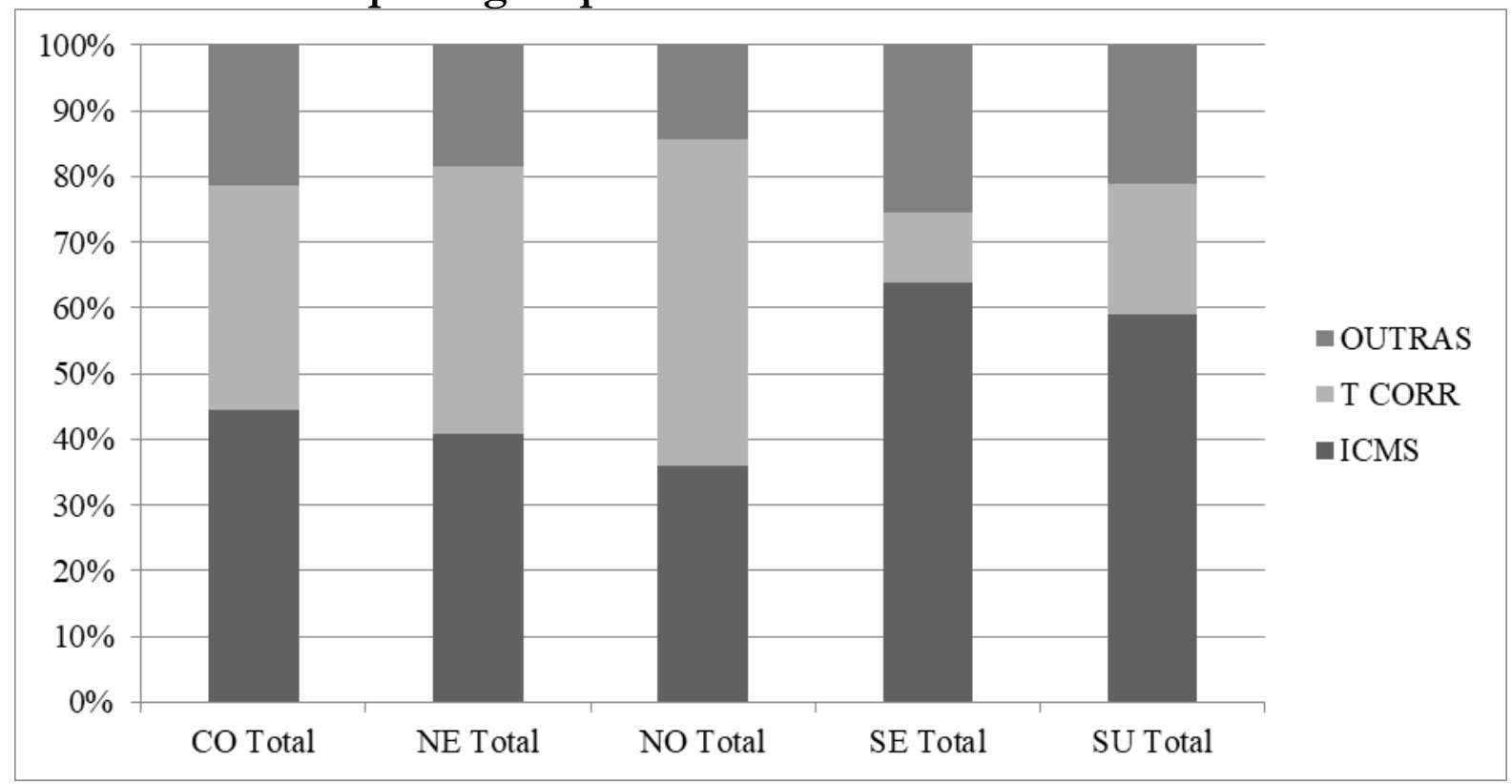

Fonte: Dados da pesquisa (2016).

Gráfico 2 - Participação do ICMS e das transferências correntes no total das receitas correntes por região para o ano de 2013

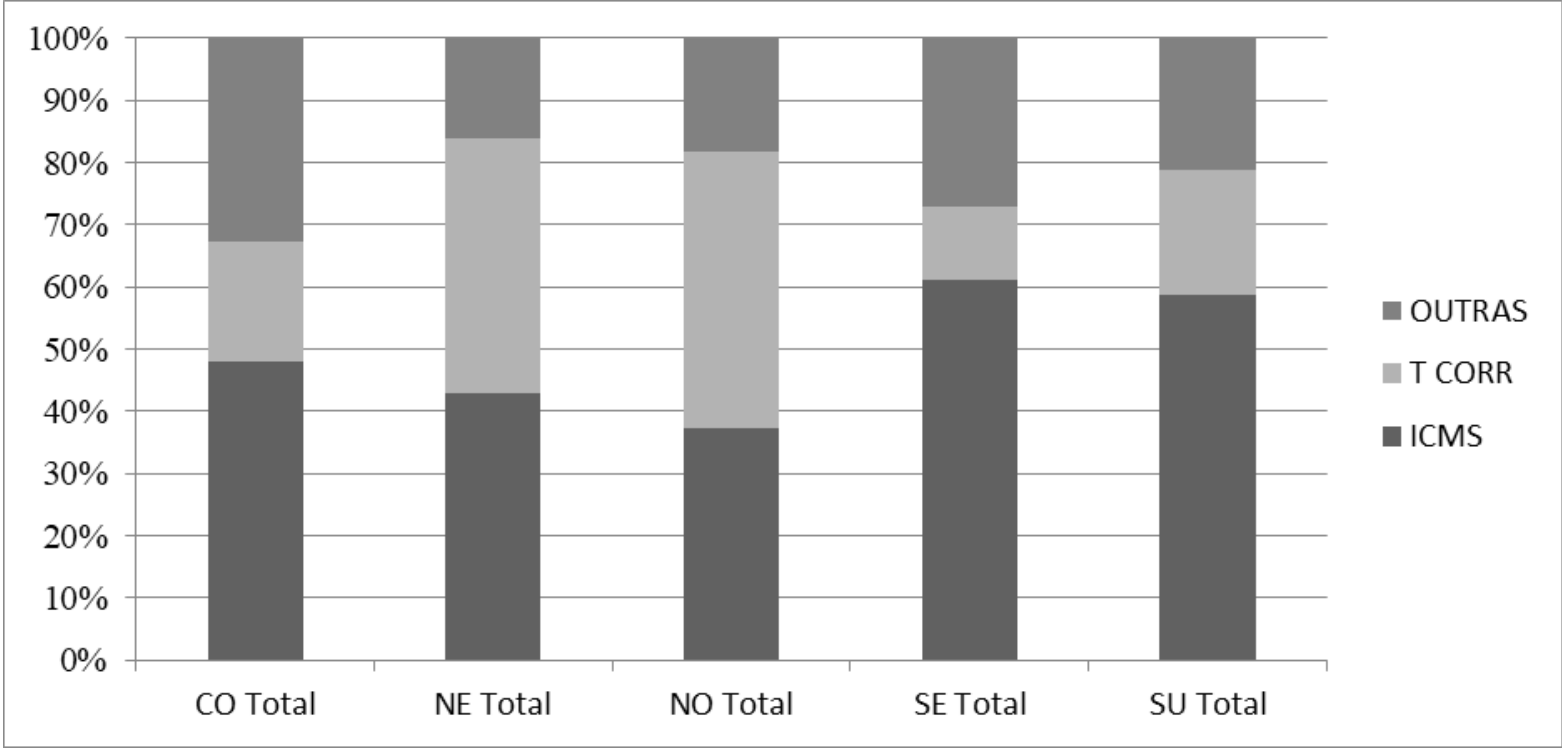

Fonte: Dados da pesquisa (2016).

Dada a concentração da maioria das competências tributárias e da maior parte das receitas públicas disponíveis sob a tutela da União, estes dados preliminares sugerem que a par da centralização governamental, como a definida por 
Tocqueville (2005), a estrutura de repartição dessas receitas públicas disponíveis reflete, também, um cunho de maior centralização administrativa. Porém, cumpre ainda a análise dessas características e sua influência sob o enfoque de instituições política e economicamente inclusivas, bem como de instituições corporativistas.

Essa definição, contudo, somente pode ser feita analisando as informações constantes da arrecadação de tributos federais e estaduais nas unidades federadas, que constituem o custo dos serviços públicos disponíveis aos cidadãos, com os valores referentes aos gastos nos serviços assim financiados. Cumpre, portanto, primeiramente analisar as informações referentes à arrecadação dos tributos federais em cada estado, bem como as receitas tributárias próprias que irão compor o total dos tributos federais e estaduais cobrados nos estados.

Da soma da arrecadação de tributos federais e estaduais, e sua divisão pelo PIB dos estados, pode-se aquilatar a carga tributária federal e estadual em cada ente subnacional, para verificar se há equivalência entre eles na relação entre o volume de tributos cobrados e o tamanho da economia. Estes dados preliminares apontam diferença entre suas cargas tributárias relativas. A tabulação dessas informações constam nas Tabelas 4 e 5 , que informam o total de tributos federais e estaduais e o percentual da carga total de tributos em relação aos PIBs estaduais para os anos de 2002 e 2013: 
Tabela 4 - Comparação da relação entre o volume de tributos federais e estaduais cobrados em cada estado e o respectivo PIB estadual no ano de 2002

\begin{tabular}{|c|c|c|c|c|c|}
\hline Estados federados & Tributos federais & Tributos estaduais & Carga trib. total & PIB estadual & $\begin{array}{l}\text { Carga } \\
\text { relativa }\end{array}$ \\
\hline Distrito Federal & $23.085 .755 .389,00$ & $2.939 .353 .841,44$ & $26.025 .109 .230,44$ & 56.137 .983 .806 & $46,36 \%$ \\
\hline Goiás & $1.792 .755 .545,00$ & $3.353 .348 .832,22$ & $5.146 .104 .377,22$ & 37.415.997.218 & $13,75 \%$ \\
\hline Mato Grosso do Sul & $564.724 .796,00$ & $1.508 .423 .784,40$ & $2.073 .148 .580,40$ & 15.153 .544 .468 & $13,68 \%$ \\
\hline Mato Grosso & $726.551 .450,00$ & $2.033 .963 .329,11$ & $2.760 .514 .779,11$ & 20.941 .060 .274 & $13,18 \%$ \\
\hline Centro-Oeste & $26.169 .787 .180,00$ & $9.835 .089 .787,17$ & $36.004 .876 .967,17$ & 129.648 .585 .766 & $27,77 \%$ \\
\hline Alagoas & $378.502 .690,00$ & $742.194 .750,00$ & $1.120 .697 .440,00$ & 9.812 .400 .798 & $11,42 \%$ \\
\hline Bahia & 5.288.077.377,00 & $5.383 .113 .686,42$ & $10.671 .191 .063,42$ & 60.671 .842 .701 & $17,59 \%$ \\
\hline Ceará & $1.934 .092 .185,00$ & 2.624.605.009,90 & 4.558.697.194,90 & 28.896.188.092 & $15,78 \%$ \\
\hline Maranhão & $1.083 .748 .594,00$ & $1.028 .522 .170,16$ & $2.112 .270 .764,16$ & 15.448 .774 .488 & $13,67 \%$ \\
\hline Paraíba & $616.317 .091,00$ & $1.013 .222 .610,46$ & $1.629 .539 .701,46$ & 12.433 .902 .137 & $13,11 \%$ \\
\hline Pernambuco & $2.795 .425 .256,00$ & $3.236 .951 .428,87$ & $6.032 .376 .684,87$ & 35.251 .387 .497 & $17,11 \%$ \\
\hline Piauí & $357.778 .987,00$ & $598.794 .521,69$ & $956.573 .508,69$ & 7.425 .109 .330 & $12,88 \%$ \\
\hline Rio Grande do Norte & & $1.187 .913 .579,04$ & & & $14,73 \%$ \\
\hline Sergipe & $512.782 .807,00$ & 724.334.781,61 & $1.237 .117 .588,61$ & 9.454 .444 .214 & $13,09 \%$ \\
\hline Nordeste & $13.575 .744 .170,00$ & $16.539 .652 .538,15$ & $30.115 .396 .708,15$ & 191.591.602.994 & $15,72 \%$ \\
\hline Acre & $84.138 .308,00$ & $220.084 .338,05$ & $304.222 .646,05$ & 2.868 .451 .380 & $10,61 \%$ \\
\hline Amazonas & $2.698 .670 .433,00$ & $2.077 .609 .765,46$ & $4.776 .280 .198,46$ & 21.791.161.866 & $21,92 \%$ \\
\hline Amapá & $124.430 .068,00$ & $162.194 .038,27$ & $286.624 .106,27$ & 3.291 .534 .122 & $8,71 \%$ \\
\hline Pará & $1.204 .214 .867,00$ & $1.903 .335 .674,90$ & $3.107 .550 .541,90$ & 25.659.110.882 & $12,11 \%$ \\
\hline Rondônia & $312.891 .697,00$ & $697.028 .039,13$ & $1.009 .919 .736,13$ & 7.779 .879 .996 & $12,98 \%$ \\
\hline Roraima & $96.289 .767,00$ & $138.456 .433,00$ & $234.746 .200,00$ & 2.312 .646 .147 & $10,15 \%$ \\
\hline Tocantins & $128.417 .367,00$ & $466.621 .010,61$ & $595.038 .377,61$ & 5.607 .172 .803 & $10,61 \%$ \\
\hline Norte & 4.649.052.507,00 & $5.665 .329 .299,42$ & $10.314 .381 .806,42$ & 69.309.957.195 & $14,88 \%$ \\
\hline Espírito Santo & $2.655 .867 .136,00$ & $2.705 .983 .587,21$ & $5.361 .850 .723,21$ & 26.756 .050 .051 & $20,04 \%$ \\
\hline Minas Gerais & $11.513 .183 .623,00$ & 11.152.092.656,05 & $22.665 .276 .279,05$ & 127.781.907.197 & $17,74 \%$ \\
\hline Rio de Janeiro & $40.406 .738 .367,00$ & $12.089 .143 .589,72$ & $52.495 .881 .956,72$ & 171.371 .993 .050 & $30,63 \%$ \\
\hline São Paulo & $99.107 .109 .745,00$ & 41.102.869.021,91 & 140.209.978.766,91 & 511.735.917.636 & $27,40 \%$ \\
\hline Sudeste & $153.682 .898 .871,00$ & $67.050 .088 .854,89$ & $220.732 .987 .725,89$ & 837.645 .867 .934 & $26,35 \%$ \\
\hline Paraná & $9.387 .044 .061,00$ & $6.295 .975 .004,28$ & $15.683 .019 .065,28$ & 88.407.076.015 & $17,74 \%$ \\
\hline Rio Grande do Sul & $10.404 .353 .062,00$ & $8.016 .083 .680,38$ & $18.420 .436 .742,38$ & 105.486 .816 .448 & $17,46 \%$ \\
\hline Santa Catarina & $4.436 .283 .139,00$ & $4.272 .003 .589,39$ & 8.708.286.728,39 & 55.731 .862 .649 & $15,63 \%$ \\
\hline Sul & $24.227 .680 .262,00$ & $18.584 .062 .274,05$ & $42.811 .742 .536,05$ & 249.625 .755 .111 & $17,15 \%$ \\
\hline
\end{tabular}

Fonte: Dados da pesquisa (2016). 
Tabela 5 - Comparação da relação entre o volume de tributos federais e estaduais cobrados em cada estado e o respectivo PIB estadual no ano de 2013

\begin{tabular}{|c|c|c|c|c|c|}
\hline Estados federados & Tributos federais & Tributos estaduais & Carga trib. total & PIB estadual & $\begin{array}{c}\text { Carga } \\
\text { relativa }\end{array}$ \\
\hline Distrito Federal & 78.135 .278 .212 & $11.443 .797 .300,60$ & $89.579 .075 .512,60$ & 175.363 .000 .000 & $51,08 \%$ \\
\hline Goiás & 8.595 .300 .845 & $15.601 .376 .108,64$ & $24.196 .676 .953,64$ & 151.010.000.000 & $16,02 \%$ \\
\hline Mato Grosso do Sul & 3.048 .297 .390 & 7.163.028.109,14 & 10.211.325.499,14 & 69.118 .000 .000 & $14,77 \%$ \\
\hline Mato Grosso & 3.955 .496 .869 & $8.790 .504 .020,62$ & $12.746 .000 .889,62$ & 89.124 .000 .000 & $14,30 \%$ \\
\hline Centro-Oeste & 93.734 .373 .316 & $42.998 .705 .539,00$ & $136.733 .078 .855,00$ & 484.615 .000 .000 & $28,21 \%$ \\
\hline Alagoas & 1.634 .930 .821 & $3.203 .360 .394,32$ & 4.838.291.215,32 & 37.223 .000 .000 & $13,00 \%$ \\
\hline Bahia & 15.213 .322 .397 & $18.476 .905 .636,40$ & $33.690 .228 .033,40$ & 204.265 .000 .000 & $16,49 \%$ \\
\hline Ceará & 8.927.113.678 & $10.150 .885 .779,50$ & $19.077 .999 .457,50$ & 108.796.000.000 & $17,54 \%$ \\
\hline Maranhão & 3.766 .237 .239 & $5.186 .648 .732,46$ & 8.952.885.971,46 & 67.593 .000 .000 & $13,25 \%$ \\
\hline Paraíba & 2.804 .645 .874 & $4.567 .613 .850,41$ & $7.372 .259 .724,41$ & 46.325 .000 .000 & $15,91 \%$ \\
\hline Pernambuco & 12.621 .569 .194 & $13.442 .144 .059,61$ & $26.063 .713 .253,61$ & 140.728 .000 .000 & $18,52 \%$ \\
\hline Piauí & 1.545 .963 .153 & $3.196 .932 .278,69$ & $4.742 .895 .431,69$ & 31.240 .000 .000 & $15,18 \%$ \\
\hline Rio Grande do Norte & 2.648 .709 .037 & $4.840 .615 .842,61$ & 7.489.324.879,61 & 51.446 .000 .000 & $14,56 \%$ \\
\hline Sergipe & 1.927 .849 .232 & $2.980 .854 .485,90$ & 4.908.703.717,90 & 35.193 .000 .000 & $13,95 \%$ \\
\hline Nordeste & 51.090 .340 .625 & $66.045 .961 .059,90$ & 117.136.301.684,90 & 722.809 .000 .000 & $16,21 \%$ \\
\hline Acre & 435.435 .780 & $1.015 .486 .448,49$ & $1.450 .922 .228,49$ & 11.440 .000 .000 & $12,68 \%$ \\
\hline Amazonas & 10.097 .835 .347 & 8.082.887.123,78 & 18.180.722.470,78 & 83.293 .000 .000 & $21,83 \%$ \\
\hline Amapá & 473.858 .700 & $906.016 .400,54$ & $1.379 .875 .100,54$ & 12.762 .000 .000 & $10,81 \%$ \\
\hline Pará & 4.570 .478 .436 & $9.220 .095 .189,27$ & $13.790 .573 .625,27$ & 120.949 .000 .000 & $11,40 \%$ \\
\hline Rondônia & 1.308 .879 .482 & $3.083 .087 .176,80$ & $4.391 .966 .658,80$ & 31.092 .000 .000 & $14,13 \%$ \\
\hline Roraima & 460.214 .080 & $652.407 .256,88$ & 1.112.621.336,88 & 9.027 .000 .000 & $12,33 \%$ \\
\hline Tocantins & 860.678 .765 & $2.212 .458 .445,88$ & $3.073 \cdot 137.210,88$ & 23.778.000.000 & $12,92 \%$ \\
\hline Norte & 18.207 .380 .590 & $25.172 .438 .041,64$ & 43.379.818.631,64 & 292.341 .000 .000 & $14,84 \%$ \\
\hline Espírito Santo & 13.542 .209 .548 & $10.003 .811 .743,47$ & 23.546.021.291,47 & 117.043 .000 .000 & $20,12 \%$ \\
\hline Minas Gerais & 42.080 .866 .476 & $43.482 .387 .817,82$ & $85.563 .254 .293,82$ & 486.955 .000 .000 & $17,57 \%$ \\
\hline Rio de Janeiro & 129.264 .203 .100 & $40.612 .374 .424,66$ & $169.876 .577 .524,66$ & 626.320 .000 .000 & $27,12 \%$ \\
\hline São Paulo & 318.357 .330 .144 & $130.553 .599 .150,0$ & $448.910 .929 .294,03$ & 1.708.221.000.00 & $26,28 \%$ \\
\hline Sudeste & 503.244 .609 .268 & 224.652.173.135,9 & $727.896 .782 .403,98$ & 2.938 .539 .000 .00 & $24,77 \%$ \\
\hline Paraná & 40.486 .353 .960 & 24.631.471.873,20 & $65.117 .825 .833,20$ & 332.837 .000 .000 & $19,56 \%$ \\
\hline Rio Grande do Sul & 34.717 .871 .051 & 28.594.292.601,17 & $63.312 .163 .652,17$ & 331.095 .000 .000 & $19,12 \%$ \\
\hline Santa Catarina & 26.760 .518 .651 & 16.564.138.994,39 & 43.324.657.645,39 & 214.217 .000 .000 & $20,22 \%$ \\
\hline Sul & 101.964.743.662 & $69.789 .903 .468,76$ & 171.754.647.130,76 & 878.149 .000 .000 & $19,56 \%$ \\
\hline
\end{tabular}

Fonte: Dados da pesquisa (2016).

O custo dos serviços públicos colocados à disposição do contribuinte é financiado com o valor dos tributos pagos. Para verificar se a economia de escala do estado ao prestar esses serviços constitui uma relação custo-benefício mais vantajosa ao contribuinte do que se contratasse individualmente os mesmos serviços, é possível relacionar a imposição tributária e o volume dos gastos públicos realizados nos entes subnacionais. Nas Tabelas 6 e 7 é verificada a proporção da despesa total e a carga tributária federal e estadual nos estados. Esses dados permitem identificar uma relação custo-benefício entre a imposição tributária e o gasto em serviços 
públicos inversa entre as regiões Norte, Nordeste e Centro-Oeste (excetuando-se o Distrito Federal), e as regiões Sul e Sudeste e o Distrito Federal:

\section{Tabela 6 - Comparação da relação entre a o volume de tributos federais e estaduais cobrados em cada estado e a respectiva despesa estadual total no ano de 2002}

\begin{tabular}{lccc}
\hline Estados federados & Carga trib. total & Despesa total & Relação \\
\hline Distrito Federal & $26.025 .109 .230,44$ & $7.130 .706 .424,39$ & 3,65 \\
Goiás & $5.146 .104 .377,22$ & $5.143 .151 .792,01$ & 1,00 \\
Mato Grosso do Sul & $2.073 .148 .580,40$ & $2.589 .039 .524,71$ & 0,80 \\
Mato Grosso & $2.760 .514 .779,11$ & $3.134 .836 .693,67$ & 0,88 \\
Centro-Oeste & $36.004 .876 .967,17$ & $17.997 .734 .434,78$ & 2,00 \\
Alagoas & $1.120 .697 .440,00$ & $2.288 .725 .862,68$ & 0,49 \\
Bahia & $10.671 .191 .063,42$ & $9.632 .686 .769,60$ & 1,11 \\
Ceará & $4.558 .697 .194,90$ & $6.227 .242 .729,44$ & 0,73 \\
Maranhão & $2.112 .270 .764,16$ & $3.464 .238 .049,46$ & 0,61 \\
Paraíba & $1.629 .539 .701,46$ & $2.531 .193 .133,08$ & 0,64 \\
Pernambuco & $6.032 .376 .684,87$ & $7.099 .547 .222,52$ & 0,85 \\
Piauí & $956.573 .508,69$ & $1.886 .995 .174,99$ & 0,51 \\
Rio Grande do Norte & $1.796 .932 .762,04$ & $2.465 .154 .008,77$ & 0,73 \\
Sergipe & $1.237 .117 .588,61$ & $1.988 .768 .851,17$ & 0,62 \\
Nordeste & $30.115 .396 .708,15$ & $37.584 .551 .801,71$ & 0,80 \\
Acre & $304.222 .646,05$ & $1.162 .473 .061,09$ & 0,26 \\
Amazonas & $4.776 .280 .198,46$ & $3.705 .663 .762,48$ & 1,29 \\
Amapá & $286.624 .106,27$ & $959.443 .521,38$ & 0,30 \\
Pará & $3.107 .550 .541,90$ & $3.951 .388 .194,88$ & 0,79 \\
Rondônia & $1.009 .919 .736,13$ & $1.601 .209 .682,25$ & 0,63 \\
Roraima & $234.746 .200,00$ & $639.512 .701,00$ & 0,37 \\
Tocantins & $595.038 .377,61$ & $1.841 .074 .211,15$ & 0,32 \\
Norte & $10.314 .381 .806,42$ & $13.860 .765 .134,23$ & 0,74 \\
Espírito Santo & $5.361 .850 .723,21$ & $3.710 .279 .696,87$ & 1,45 \\
Minas Gerais & $22.665 .276 .279,05$ & $18.469 .164 .479,95$ & 1,23 \\
Rio de Janeiro & $52.495 .881 .956,72$ & $20.396 .932 .189,23$ & 2,57 \\
São Paulo & $140.209 .978 .766,91$ & $52.420 .669 .489,58$ & 2,67 \\
Sudeste & $220.732 .987 .725,89$ & $94.997 .045 .855,63$ & 2,32 \\
Paraná & $15.683 .019 .065,28$ & $9.829 .166 .437,24$ & 1,60 \\
Rio Grande do Sul & $18.420 .436 .742,38$ & $12.619 .638 .514,60$ & 1,46 \\
Santa Catarina & $8.708 .286 .728,39$ & $7.190 .840 .784,54$ & 1,21 \\
Sul & $42.811 .742 .536,05$ & $29.639 .645 .736,38$ & 1,44 \\
\hline
\end{tabular}

Fonte: Dados da pesquisa (2016). 
Tabela 7 - Comparação da relação entre o volume de tributos federais e estaduais cobrados em cada estado e a respectiva despesa estadual total no ano de 2013

\begin{tabular}{lccc}
\hline Estados federados & Carga trib. total & Despesa total & Relação \\
\hline Distrito Federal & $89.579 .075 .512,60$ & $18.133 .089 .572,58$ & 4,94 \\
Goiás & $24.196 .676 .953,64$ & $18.606 .248 .083,17$ & 1,30 \\
Mato Grosso do Sul & $10.211 .325 .499,14$ & $11.712 .097 .316,76$ & 0,87 \\
Mato Grosso & $12.746 .000 .889,62$ & $12.721 .613 .392,81$ & 1,00 \\
Centro-Oeste Total & $136.733 .078 .855,00$ & $61.173 .048 .365,32$ & 2,24 \\
Alagoas & $4.838 .291 .215,32$ & $7.092 .907 .991,05$ & 0,68 \\
Bahia & $33.690 .228 .033,40$ & $34.237 .808 .085,76$ & 0,98 \\
Ceará & $19.077 .999 .457,50$ & $18.395 .140 .660,60$ & 1,04 \\
Maranhão & $8.952 .885 .971,46$ & $14.093 .110 .891,85$ & 0,64 \\
Paraíba & $7.372 .259 .724,41$ & $8.559 .088 .409,37$ & 0,86 \\
Pernambuco & $26.063 .713 .253,61$ & $27.132 .767 .346,56$ & 0,96 \\
Piauí & $4.742 .895 .431,69$ & $7.351 .676 .058,39$ & 0,65 \\
Rio Grande do Norte & $7.489 .324 .879,61$ & $9.873 .887 .196,34$ & 0,76 \\
Sergipe & $4.908 .703 .717,90$ & $6.988 .408 .508,08$ & 0,70 \\
Nordeste Total & $117.136 .301 .684,90$ & $133.724 .795 .148,00$ & 0,88 \\
Acre & $1.450 .922 .228,49$ & $5.156 .552 .725,91$ & 0,28 \\
Amazonas & $18.180 .722 .470,78$ & $14.569 .525 .924,39$ & 1,25 \\
Amapá & $1.379 .875 .100,54$ & $4.481 .367 .347,76$ & 0,31 \\
Pará & $13.790 .573 .625,27$ & $16.616 .549 .242,41$ & 0,83 \\
Rondônia & $4.391 .966 .658,80$ & $6.479 .108 .791,86$ & 0,68 \\
Roraima & $1.112 .621 .336,88$ & $3.879 .887 .764,72$ & 0,29 \\
Tocantins & $3.073 .137 .210,88$ & $6.626 .509 .400,43$ & 0,46 \\
Norte Total & $43.379 .818 .631,64$ & $57.809 .501 .197,48$ & 0,75 \\
Espírito Santo & $23.546 .021 .291,47$ & $13.721 .665 .464,74$ & 1,72 \\
Minas Gerais & $85.563 .254 .293,82$ & $71.906 .529 .761,80$ & 1,19 \\
Rio de Janeiro & $169.876 .577 .524,66$ & $71.663 .151 .028,69$ & 2,37 \\
São Paulo & $448.910 .929 .294,03$ & $197.870 .171 .922,07$ & 2,27 \\
Sudeste Total & $727.896 .782 .403,98$ & $355.161 .518 .177,30$ & 2,05 \\
Paraná & $65.117 .825 .833,20$ & $32.047 .015 .544,58$ & 2,03 \\
Rio Grande do Sul & $63.312 .163 .652,17$ & $45.762 .263 .619,71$ & 1,38 \\
Santa Catarina & $43.324 .657 .645,39$ & $19.254 .339 .864,11$ & 2,25 \\
Sul Total & $171.754 .647 .130,76$ & $97.063 .619 .028,40$ & 1,77 \\
\hline
\end{tabular}

Fonte: Dados da pesquisa (2016).

As aproximações efetuadas nas Tabelas 6 e 7 indicam a média de arrecadação de tributos federais e estaduais nos estados para cada real gasto pelos referidos entes subnacionais e pela União nos mesmos. Os dados por região indicam que na Região Centro-Oeste, em 2002, para cada R $\$ 1$ gasto, eram cobrados em tributos $\mathrm{R} \$ 2$. Porém, essa média leva em conta o Distrito Federal, que destoa dos números das demais unidades da região. $\mathrm{Na}$ Região Nordeste, a relação variou de $\mathrm{R} \$ 0,80$ de tributos cobrados para $\mathrm{R} \$ 0,88$, para cada $\mathrm{R} \$ 1$ gasto na região. Na Região Norte, 
a variação entre a arrecadação e os gastos públicos variou de $\mathrm{R} \$ 0,74$ para $\mathrm{R} \$ 0,75$. $\mathrm{Na}$ Região Sul variou de R\$1,44 para R\$1,77. Na Região Sudeste variou de R\$ 2,32 para $\mathrm{R} \$ 2,05$. Pode-se determinar, então, que o custo relativo dos serviços públicos é diferente nas regiões do país, com vieses de variação diferentes também. Sob esses aspectos, pode-se afirmar que as instituições formais referentes ao pacto federativo fiscal estabelecem incentivos para investir e poupar igualmente diferentes nas regiões subnacionais, permitindo afirmar que sua caracterização como mais próximas de inclusivas ou de extrativistas é diferente nos estados e regiões brasileiras.

\section{Considerações finais}

Efetivamente há diferenças entre o Produto Interno Bruto dos estados e sua participação no Produto Interno Bruto nacional. No período analisado as Regiões Norte e Nordeste aumentaram sua participação no PIB nacional em 0,6\% cada uma. A Região Centro-Oeste aumentou exato 1\%, tendo tido um crescimento de pouco menos de um décimo de um por cento ao ano. $\mathrm{O}$ aumento da participação dessas regiões reflete-se nas regiões Sul e Sudeste, que diminuíram sua participação relativa em $0,7 \%$ e $1,5 \%$, respectivamente. Representam uma diminuição nas desigualdades regionais, ainda muito agudas, principalmente levando-se em conta o PIB per capita dos estados e do Distrito Federal. Como visto, a federação brasileira pode ser definida como solidária pelo sistema constitucional de repartição das receitas tributárias, que privilegia as transferências correntes dos estados das Regiões Norte, Nordeste e Centro-Oeste. Ao analisar os indicadores por região, verifica-se que a relação custo/benefício dos serviços públicos é heterogênea, determinando direitos de propriedade e incentivos desiguais entre os estados.

\section{Referências}

ACEMOGLU, Daron; ROBINSON, James. Porque as nações fracassam: as origens da riqueza, da prosperidade e da pobreza. Rio de Janeiro: Elsevier, 2012.

ALMEIDA, LUIZ. Introdução ao Direito Econômico. 4 ed. São Paulo: Saraiva, 2011.

BRASIL. Constituição da República Federativa do Brasil. Brasília: Senado Federal, 1988. 
BRASIL. Lei Complementar N. 62, de 28 de Dezembro de 1989. Estabelece normas sobre o cálculo, a entrega e o controle das liberações dos recursos dos Fundos de Participação e dá outras providências. Diário Oficial [da República Federativa do Brasil], Brasília/DF, 29 dez. 1989.

BONAVIDES, Paulo. Ciência Política. 10 ed. São Paulo: Editora Malheiros, 2001.

CANOTILHO, José Joaquim Gomes. Direito Constitucional. Coimbra: Livraria Almedina, 1993.

CARGA TRIBUTÁRIA BRASILEIRA 2013. Centro de Estudos Tributários e Aduaneiros. Brasília: Receita Federal, 2014. Disponível em:

$<$ http://idg.receita.fazenda.gov.br/dados/receitadata/estudos-e-tributarios-eaduaneiros/estudos-e-estatisticas/carga-tributaria-no-brasil $>$. Acesso em 28/04/2015.

CARRAZA, Roque Antonio. Curso de Direito Constitucional Tributário. 30 ed. São Paulo: Malheiros, 2015.

GALÍPOLO, Gabriel; GALA, Paulo; FERNANDES, Danilo Araújo. Notas para uma avaliação do discurso marxista em Douglass North. Revista EconomiA, 9 (1), p. 195-213, 2008.

NORTH, Douglas. Institutions, institutional change and economic performance. Nova Iorque: Cambridge University Press, 1990.

NOVELINO, Marcelo. Manual de Direito Constitucional. 8 ed. São Paulo: Editora Método, 2013.

PHELPS, Edmund S. What is wrong with the west's economies? Nova Iorque: The New York Review of Books, 2015.

PHELPS, Edmund S. Mass flourishing: how grassroots innovation created jobs, challenge, and change. Princeton: Princeton University Press, 2013. 
SISTEMA DE INFORMAÇÕES CONTÁBEIS E FISCAIS DO PODER PÚBLICO BRASILEIRO. Disponível em:

$<$ https://siconfi.tesouro.gov.br/siconfi

/pages/public/declaracao/declaracao_list.jsf>. Acesso em 27/04/2015.

TOCQUEVILLE, Aléxis de. A democracia na América (livro 1: leis e costumes). Trad. Eduardo Brandão. São Paulo: Martins Fontes, 2005.

Endereço para correspondência:

Marcelo Dalton Dalmolin - marcelo.dalmolin@hotmail.com

Rua Clotário Portugal, 1051 - Centro

84600-000 União da Vitória/PR, Brasil

Carlos Eduardo Carvalbo - carloseduardo@unc.br

Avenida Doutor Leoberto Leal, 1904 - Bairro N. S. Aparecida 89520-000 Curitibanos/SC, Brasil 